\title{
Believe in Me: Insights of a Nonspeaking College-Bound Autistic
}

\author{
Rachel Kripke-Ludwig
}

Keywords: autism, self-advocate, neurodiversity, college, nonspeaking, anxiety

$\mathbf{S}^{\mathrm{r}}$ PECIAL EDUCATION NEARLY KILLED my will to live. As a nonspeaking autistic person, I had no way to share my thoughts with the world for the first 13 years of my life. Open Mind School changed my trajectory. Before I transferred, like most of my peers, I was trapped in a segregated school. There, I was doing peg boards and circle time with no hope of escape. My mothers tried Picture Exchange Communication System (PECS) ${ }^{\circledR}$ and various speech output devices, but they were minimally effective. My first big break came when I learned to control my movement enough to spell on a letter board. Eventually, I found my voice through spelling. But even when I could communicate with my parents, I did not have support at school. My new school was willing to support me and give me a real education. Today, I am college bound.

Five years after learning to communicate on a letter board, I wanted to reflect on what it took to get me to a place where college is a realistic goal. First, I had to transition away from TEACCH stations, SCERTS exercises, sensory gyms, and other standard therapies for autism. Although well intentioned, they did not help, and are not designed for college preparation. I was doing grade-level work at home. However, the school district continued to try to steer me toward a functional curriculum. The district's Content Specialist questioned the value of an academic education for someone like me who will always need support and who could not produce the full volume of assignments at the time. She felt my mothers should be realistic and give up on the idea of a diploma. She recommended enrolling me in social and life skills studies. I needed help with life skills, but killing my motivation was not the answer. When I have opportunities that I do not want to miss, my self-regulation improves. After a year of lessons at home to catch me up academically, I had demonstrated my capacity, but because my old school did not want to adapt, they did not want to serve me anymore. I had to find another solution.

I transferred schools just as I was developing the stamina to communicate in full sentences on a letter board. I was a mess of emotions and anxiety. I had 13 years of silence to make up for, and my puberty hormones were distressing me. For several years, I thought that after graduation, the most I could hope for was private tutoring or online extension school classes. I needed teachers who could see my potential before I could see my own. A classroom aide, Matt Jacobs, was the catalyst for helping me change what I see as possible. Matt is a University of California Santa Cruz (UCSC) undergraduate in cognitive science who was hired a few years ago as a classroom supporter and enrichment teacher. Before coming to my school, he had no professional experience in autism. He arranged a formative experience that changed how I saw my life trajectory.

When I changed schools, my disability did not change. The people who were around me did. They believed in me. Matt could see that I was doing grade-level work. He and my teachers thought that college was something I could realistically learn to manage if in a supportive university. But the thought of navigating a college campus and sitting in a lecture hall was inconceivable to me. I was, and still am, nonspeaking, impulsive, and need to move to pay attention.

A couple of years ago, Matt arranged for me to visit his classes and professors at UCSC. I worried that I would be thwarted by the principal of my school because I can be disruptive in a place where calm quiet regulation is expected. I have opened car doors during transport on the freeway and thrown objects out the window. She knew this but did not project worry. Instead, she arranged for me to have my regular classroom aide and Matt help me, knowing I would be safe and participate with their support. I did have to get up and move and make vocalizations, but I contributed to the learning of psychology students as well. Professor Rebecca Covarrubias did not flinch or get anxious, so the students did not either. She invited me to ask prepared questions during her office hours, and she encouraged me to apply to UCSC.

Students at UCSC understand the value of diversity. In the 1980s, school administrators decided that the slug mascot was undignified and tried to change it to a seal. But the students would not have it. ${ }^{1}$ Now, in honor of the lowly slug, student pranksters regularly paint the seal statue yellow. Diversity is healthy, and everybody makes a critical contribution. Banana Slugs are hidden from sight, waiting to show their bright colors to the world. I am a Slug emerging from

Open Mind School, Menlo Park, California, USA.

(C) Rachel Kripke-Ludwig, 2020; Published by Mary Ann Liebert, Inc. This Open Access article is distributed under the terms of the Creative Commons License (https://creativecommons.org/licenses/by-nc-nd/3.0/), which permits any non-modified noncommercial use, distribution, and reproduction in any medium, provided the original author(s) and the source are cited. 
rainy days behind me. Now, my dream is to be a Banana Slug at UCSC. I want to live in the dorms. I want to be fully included in campus life. I want a chance to paint the seal statue outside Thimann Hall yellow.

\section{Creating Open Minds and Healthy Environments}

It was the unconscious biases of special educators that held me back. They were taught that I cannot learn, so they did not provide grade-level lessons. But I can and must learn everything other kids do. Knowledge is power. Keeping me from information disempowers me and causes anxiety. It guarantees my second-class status.

I wanted to learn more about how we can teach a different narrative to educators. I interviewed Matt, not because of his training, but because he was someone who was effective at helping me grow. I distilled my conversation with Matt into three themes. First, unconscious biases are supported or suppressed early. Second, the neurodiversity movement is helping shape the attitudes of the general population toward nonspeaking and high-need people like me. Third, respect and reciprocity are key to creating a supportive environment.

\section{Attitudes Form Early}

Matt shared that his open mind was supported by his parents. His sister was his idol. She wanted to play with Barbies, so he played with Barbies. They also played G.I. Joe. His sister wanted to do theater, so he started to do theater. Their parents did not interfere. "There wasn't quite the language or the understanding that there is now, and so I was really embarrassed because I knew or I felt as if I wasn't supposed to be doing those things at the time," he said. Matt's parents did not let gender stereotypes limit him. Matt is not ashamed to talk about gender nonconforming interests now because people supported him to pursue them. Another example of the power of mentors was in high school when Matt was encouraged by a trusted teacher to go to a women's group. "I absolutely loved it," he said. "The speaker just moved me. So, I started going there. I started going to LGBTQ meetings.',

Matt's ability to keep an open mind was reinforced by peers. Before coming to Open Mind School, he had a hard lesson. He worked with a friend on a music and Alzheimer's disease project. It involved making recordings of the participants' favorite music for them to listen. This could have been pleasant or distressing. Matt remembers being very insistent, "We need family members to give consent." His project partner got extremely upset with him for not getting consent directly from the participants. "He showed me how my viewpoint was stealing agency from people, and I was not presuming competence. I was not giving people the benefit of the doubt to make their own choices in their lives about what they need...That really changed my perspective.' Matt came to Open Mind School shortly after that event, so he brought that insight with him.

\section{Influence of the Neurodiversity Movement}

Matt explained how emotions can be viewed as gifts instead of curses. The neurodiversity movement does not label our traits as good or bad, because it depends on whether our brains are overwhelming us at the moment or we are using our gifts to study or contribute. Our ability to remain regulated is contextual depending on the accommodations and attitudes in our environment.

Anxiety is Matt's gift. Like me, Matt is more aware than most, because he comes from a family of anxious people. Matt shared, "[E]veryone in my family has anxiety...My father is super claustrophobic. He doesn't like to go on elevators. I'm usually really aware of where every staircase is...[Anxiety] makes us very attentive people because we are always paying attention to everything. That is how I can take 20 kids to a pool and always have a head count within 30 seconds..."

Matt models how neurodiverse people can make a contribution, but we also need help learning to live in a body that does not cooperate all the time. Matt taught me his tips for how to live with an anxious mind. Matt uses a variety of strategies to remain regulated. He uses mindfulness, good sleep hygiene, healthy eating, avoiding drugs such as caffeine, and deep breathing. He also uses a special technique for when his mind runs wild with anxious thoughts. He imagines the thought as a bird, and watches it fly away. "I think the most important thing when helping anyone is to stay perfectly calm yourself. It is a lot easier to stay calm for others... That is why I try to find leadership opportunities as much as I can."

Matt teaches that a tree falling in the forest does not make a sound; it only makes a vibration that we can perceive as sound if we are present. I have unusually good hearing and may hear the trees when others miss them. Knowledge gains are faster when diverse minds come together. For example, I am interested in climate science. I notice things that others do not, and I concentrate for long periods of time. In a group of people with different minds, I will thrive and contribute. Remarkably creative solutions come from people with different ways of processing sensory information.

\section{Respect Is Key}

Matt reminded me that when he wanted to know more about sensory-perceptual differences, he asked me to educate him because of my unique experience. Open-minded people learn from their students and the people they serve. Matt asked me to share my thoughts about communication with Cognitive Science Student Association members at UCSC. He brought my answers to a discussion he led called, "First Person Perspectives on Sensory Perception." My answers were discussed along with the work of other nonspeaking writers such as Hari Srinivasan and Ido Kedar., 2,3

Matt respected my contribution to his learning and gave me the opportunity to teach. He summed it up, "I've had people believe in me my whole life. Would I have been able to do what I've done if someone told me I couldn't? If someone said I wasn't good enough, or someone just didn't think anything of me?',

\section{Reinventing Education}

Expectations matter. When I matriculated at my current school, for much of the day, I could not even stay in the building. Sensory overload prevented me from concentrating. The teachers brought my lessons outside and built trust that they would teach me even if my body eloped. I am now regulated at school almost all of the time. I could not have gotten there without their firm belief that I could learn even 
when I could not yet fully demonstrate it. One way I learn is from field trips to meet interesting people. My school also brings scientists, artists, entrepreneurs, personal trainers, nurses, students, and other creative people to the school. Visiting teachers lead units in their area of specialty to create ongoing meaningful experiential programs where teachers grow as much as the students do. Challenging education keeps teachers engaged. It is much more fulfilling than rote drills and nursery rhymes that bore aides as much as students.

I achieved my goal of moving from a school that emphasized functional skills to one that could provide me with college preparation despite "evidence-based practice" and "highly qualified teachers." The missing ingredients were not found in training manuals or pharmacies. It was persistent fearless people who believed I could learn who saved me from boredom and failure. It took 5 years, but because of them, I am no longer a simple forest composter. I am a bright yellow Banana Slug, a symbol of the value of all creatures.

\section{Acknowledgments}

I thank Matt Jacobs for his honest interview, openness, and role modeling. His insights are greatly appreciated. Also, thank you to Open Mind School staff for their support of my growth and development.

\section{Disclaimer}

R.K.L. is the sole author and responsible for this article. She reviewed and approved the article before submission. This article has been submitted solely to Autism in Adulthood and is not published, in press, or submitted elsewhere.

\section{Author Disclosure Statement}

No competing financial interests exist.

\section{Funding Information}

No funding was received for this article.

\section{References}

1. University of California Santa Cruz. Banana Slug Mascot. June 2017. https://www.ucsc.edu/about/mascot.html (last accessed September 22, 2019).

2. Hari Srinivasan. Hari's Blog. http://journal4hari.blogspot .com/p/my-daily-californian-articles.html (last accessed September 22, 2019).

3. Ido Kedar. Ido in Autismland. http://idoinautismland.com (last accessed September 22, 2019).

Address correspondence to: Rachel Kripke-Ludwig Open Mind School 1215 O'Brien Drive Menlo Park, CA 94025

USA

E-mail: rachel.k1@openmindschool.org 